\title{
DIMENSI WAKTU DALAM ANALISIS TIME VALUE OF MONEY DAN ECONOMIC VALUE OF TIME
}

\author{
Fetria Eka Yudiana \\ STAIN Salatiga \\ fetria_belsa@yahoo.com
}

\begin{abstract}
Abstrak
Perkembangan teori keuangan Islam dewasa ini telah menjadi masalah yang hangat diperbincangkan, seperti perdebatan mengenai konsep time value of money. Konsep ini berintikan bahwa nilai uang saat ini lebih berharga dari sejumlah uang yang sama di masa yang akan datang, sehingga landasan atau asumsi yang digunakan oleh teori ini yaitu al ghunmu bila> ghurmin (mendapatkan hasil tanpa memperhatikan resiko) dan al khara $>j$ bila $>$ dhama $>n$ (memperoleh hasil tanpa mengeluarkan suatu biaya) bertentangan dengan prinsip Islam. Positive time preference kemudian digantikan dengan konsep economic value of time. konsep ini berintikan bahwa waktulah yang memiliki nilai ekonomi, bukan uang memiliki nilai waktu.
\end{abstract}

Kata kunci: waktu, uang, nilai ekonomi

\begin{abstract}
The development of the Islamic finance theory today has become a hot issue discussed, such as polemic of the concept of time value of money. This concept cored that money today is more valuable than the same amount of money in the future, so that the grounding or assumptions used by this theory is al ghunmu bila> ghurmin (get results regardless of risk) and al khara $>j$ bila $>$ dhama $>n$ (get results without issuing a charge), and it's contrary to the principles of Islam. Then The positive time preference concept was replaced with the concept of economic value of time, this concept cored that time has economic value, not money has a time value.
\end{abstract}

Keywords: time, money, economic value 


\section{Pendahuluan}

Dalam sistem keuangan konvensional kita mengenal konsep time value of money yang dijadikan dasar pengambilan keputusan investasi. Konsep time value of money secara sederhana dapat diartikan bahwa uang memiliki nilai waktu. Nilai uang dengan jumlah yang sama saat ini tidak sama nilainya dengan nilai uang dengan jumlah yang sama dimasa yang akan datang. Konsep ini menjadi sangat penting dalam pengambilan keputusan keuangan karena adanya perbedaan dimensi waktu aliran kas. Trade-off antara uang tunai saat ini dan pada masa mendatang tergantung atau dipengaruhi oleh tingkat rate tertentu yang dapat diperoleh dengan cara melakukan investasi. Nilai uang dimasa depan dari sejumlah arus kas akan menjadi lebih besar dari nilai sekarang mengingat tingkat bunga atau nilai waktu uang adalah positif.

Konsep time value of money berintikan proses pembungaan uang secara majemuk. Sehingga proses pemajemukan ini memisahkan antara uang atau sistem moneter dengan sektor riilnya. Sektor moneter dapat selalu dipastikan keuntungannya, sementara itu sektor rill dihadapkan pada kondisi yang serba tidak pasti. Konsep ini menjadi penting untuk dikaji karena ada beberapa perbedaan pandangan menurut syariah Islam dalam hal penilaian tentang kenapa nilai waktu uang selalu positif, dan bagaimana alasan pendiskontoan dan tingkat diskonto yang digunakan. Artikel ini mencoba untuk menganalisis mengenai perbedaan dasar filosofi dan asumsi dasar konsep time value of money dan konsep economic value of time. Karena dasar perbedaan tersebut akan menggambarkan perbedaan sikap (treatment) keuangan Islam khususnya dalam menentukan parameter- parameter keputusan investasi.

\section{Konsep tentang Uang}

Uang merupakan alat tukar yang sangat vital dalam suatu perekonomian, namun ada banyak perbedaan antara sistem keuangan konvensional dengan sistem keuangan syariah, tentang konsep uang. Dalam sistem keuangan konvensional, uang dianggap seperti komoditas seperti halnya barang dan jasa yang dapat diperdagangkan, dijual serta dibeli dan dapat dijadikan objek untuk berspekulasi. Uang memiliki nilai waktu yang positif sehingga jika orang meminjamkan 
uangnya kepada orang lain maka berhak mengambil tambahan keuntungan (bunga) dengan alasan adanya aspek resiko dan adanya peluang keuntungan yang mungkin hilang karena tidak memiliki uang saat ini untuk diinvestasikan. Menurut Paul A. Samuelson uang adalah sebagai media pertukaran yang diterima secara umum. Sedangkan menurut Aristoteles seperti yang dikutip oleh Metwally, uang adalah sebagai alat tukar dan tidak untuk diperanakkan. Menurut Nopirin uang adalah segala sesuatu yang dapat dipakai untuk membayar barang atau jasa. Sedangkan berdasarkan fungsinya uang sebagai (1) alat tukar, (2) satuan hitung atau satuan nilai, (3) alat penyimpan nilai, (4) ukuran pembayaran yang tertunda.

Sedangkan dalam Islam, uang dipandang sebagai sesuatu yang tidak boleh ditimbun dan tidak boleh disia-siakan atau dihamburkan. Uang tidak dipandang sebagai suatu komoditas yang dapat diperdagangkan. Islam memandang uang sebagai alat pertukaran dan tidak memiliki nilai dalam dirinya sendiri. Sehingga Islam tidak memperbolehkan kita mengambil keuntungan tambahan (bunga) hanya karena uang disimpan di bank atau karena uang yang dipinjamkan kepada orang lain. Ada tiga fungsi uang menurut Islam, yaitu sebagai ukuran harga, sebagai media transaksi dan bukan sebagai media penyimpanan nilai (Karim, 2007: 80-82).

Uang sebagai ukuran harga adalah sebagaimana yang dikatakan oleh Imam Ghazali (w. 505 H), bahwa Allah menciptakan Dirham dan Dinar sebagai hakim penengah di antara seluruh harta agar harta diukur dengan keduanya. Sedangkan Ibn al-Qayyim (w. 751 H) mengemukakan bahwa Dinar dan Dirham adalah nilai harga barang komoditas. Nilai harga adalah ukuran yang dikenal untuk mengukur harta wajib bersifat spesifik dan akurat, tidak meninggi dan tidak juga turun. Dengan adanya uang maka nilai suatu barang dapat dan diperbandingkan.

Adapun uang sebagai media transaksi, maksudnya adalah sebagai media untuk mengubah barang dari satu bentuk ke bentuk yang lain. Uang menjadi media transaksi yang sah dan harus dapat diterima oleh siapapun serta ditetakan oleh negara. Dan ini merupakan syarat penting yang membedakan uang dengan media transaksi lainnya. Imam Nawawi berkata "Makruh bagi rakyat biasa, mencetak sendiri Dirham dan Dinar, sekalipun dari bahan yang murni, sebab wewenang untuk membuat uang ada pada pemerintah." 
Adapun fungsi uang yang tidak boleh dijadikan sebagai media penyimpanan nilai, seperti diungkapkan oleh Al Ghazali : “ kemudian disebabkan jual beli, maka muncullah kebutuhan terhadap dua mata uang. Seseorang yang menginginkan makanan kemudian menukarnya dengan kain, dari mana ia dapat mengetahui ukuran baju dari nilai makanan tersebut. Sedangkan pergaulan menginginkan terjadinya jual beli antara barang yang berbeda (Al- Kaff, Abdullah Zaky, 2002: 195).

Selain ketiga hal di atas, uang dalam Islam adalah flow concept sedangkan capital adalah stock concept. Artinya semakin cepat tingkat perputaran uang akan semakin bagus. Saving harus diinvestasikan ke sektor riil, apabila tidak maka saving bukan saja tidak mendapatkan return, tetapi juga akan dikenakan zakat. Sehingga dapat disimpulkan bahwa perbedaan konsep Islam dan konsep Konvensional adalah sebagai berikut: a) Dalam konsep Islam, uang tidak identik dengan modal sedangkan konsep konvensional uang identik dengan modal; b) Menurut konsep Islam, uang adalah publics goods, sedangkan konsep konvensional uang adalah private goods; c) Dalam konsep Islam, uang adalah flow concept, sedangkan konsep konvensional uang adalah stock concept.

Islam tidak mengakui uang sebagai komoditas, namun uang diakui sebagai alat tukar. Terdapat tiga faktor yang membedakan uang dengan komoditas yaitu:

1. Uang tidak memiliki kegunaan intrinsik, hal ini berbeda dengan komoditas, uang tidak bisa dimakan, dipaki atau digunakan secara langsung, uang hanya biasa ditukar dengan komoditas, lalu komoditas itu akan dimakan, dipakai atau digunakan, uang hanya memiliki value in exchange sementara komoditas memiliki value in exchange dan value in use sekaligus.

2. Uang tidak memerlukan kualitas untuk menentukan nilainya, dalam artian uang kertas yang sudah lusuh terbitan tahun 2007 dengan uang kertas yang masih baru misal terbitan tahun 2009 memiliki daya beli yang sama, berbeda dengan komoditas misalnya mobil, tentu akan berbeda harga mobil keluaran tahun 2007 dengan mobil keluaran tahun 2008.

3. Uang tidak memerlukan spesifikasi ketika berlakunya transaksi, sementara komoditas mempunyai sifat spesifik ketika berlakunya transaksi. 


\section{Konsep Riba dan Bunga (Interest)}

Sejarah telah mencatat bahwa kata riba dikenal sebagai istilah yang sangat erat kaitannya dengan kegiatan ekonomi. Kata riba berasal dari bahasa Arab, Secara etimologis kata 'al-riba' bermakna 'al-ziyadah' yang berarti tambahan dan tumbuh, 'al-numuw' yang berarti berkembang, 'al-uluw' yang berarti membesar dan 'al-irtifa' yang berarti meningkat. Riba secara harfiah berarti tambahan atau lebihan. Saat ini riba diidentikan dengan bunga (Ali, 2008: 78). Bunga adalah imbalan yang dibayarkan oleh peminjam atas dana yang diterima, dan biasanya dinyatakan dalam persen (Tim Penyusun BI, 1999: 47). Sedangkan secara terminologis, riba secara umum didefinisikan sebagai kelebihan keuntungan (harta) dari salah satu pihak terhadap pihak lain dalam transaksi jual beli atau pertukaran barang yang sejenis dengan tanpa memberikan imbalan terhadap kelebihan tersebut (Al-Jaziri, 1972: 221). Berdasarkan kutipan Fatwa MUI No.1 Tahun 2004 pengertian bunga adalah tambahan yang dikenakan dalam transaksi pinjaman uang (al-qardh) yang diperhitungkan dari pokok pinjaman tanpa mempertimbangkan pemanfaatan/ hasil pokok tersebut, berdasarkan tempo waktu, diperhitungkan secara pasti dimuka dan pada umumnya berdasarkan persentase. Dan pengertian riba adalah tambahan (ziyadah) tanpa imbalan yang terjadi karena penangguhan dalam pembayaran yang diperjanjikan sebelumnya.

Riba sering diterjemahkan dalam bahasa Inggris sebagai "usury" yang berarti tambahan uang atas modal yang diperoleh dengan cara yang dilarang oleh syara', baik dengan jumlah tambahan yang sedikit ataupun dengan jumlah tambahan yang banyak. Sehingga dapat ditarik benang merah bahwa riba adalah tambahan yang disyaratkan dan harus dibayarkan oleh salah satu pihak ketika menerima pinjaman sejumlah uang dengan alasan adanya perbedaan nilai oleh adanya perbedaan waktu.

Bunga dalam beberapa dimensi dapat dijelaskan sebagai berikut: 1) Penentuan bunga dibuat pada waktu akad dengan asumsi harus selalu untung; 2) Besarnya persentase berdasarkan pada jumlah uang (modal) yang dipinjamkan; 3) Pembayaran bunga tetap seperti yang dijanjikan tanpa pertimbangan apakah proyek yang dijalankan oleh pihak nasabah untung atau rugi; 4) Jumlah pembayaran bunga tidak meningkat sekalipun jumlah keuntungan berlipat pada saat keadaan ekonomi sedang "booming"; 5) Eksistensi bunga diragukan oleh beberapa kalangan. 


\section{Konsep Dasar Time Value of Money}

Konsep time value of money menyatakan bahwa utilitas uang saat ini lebih tinggi dibandingkan dengan utulitasnya untuk uang dengan jumlah yang sama di waktu yang akan datang. Konsep ini secara tidak langsung merepresentasikan time preference pelaku ekonomi dalam memegang uang. Berdasarkan konsep ini seorang pelaku ekonomi sudah diasumsikan akan lebih cenderung memegang uang saat ini daripada dimasa yang akan datang, karena manusia hanya digerakkan oleh dirinya sendiri. Dalam konsep ini bunga dijustifikasikan atas modal yang dipinjamkan. Konsep time value of money secara sederhana menjelaskan bahwa jika nilai guna uang pinjaman bagi yang dipinjamkan kepada peminjam adalah sama dengan nilai uang pada masa yang akan datang, maka pemberi pinjaman akan menambahkan bunga, sehingga nilai uang di masa yang akan datang adalah sama dengan nilai uang pada saat ini.

Dengan demikian, menurut ekonomi konvensional, ada dua hal yang mendasari konsep time value of money, yaitu:

\section{Presence of Inflation}

Adanya tingkat inflasi sehingga menjadi dasar perbedaan nilai waktu uang, sebagai ilustrasi misalkan jika tingkat inflasi sepuluh persen, maka seseorang dapat membeli lima potong kue dengan hanya membayar seribu rupiah. Namun jika membelinya tahun depan maka dengan jumlah uang yang sama, dia hanya akan dapat membeli tiga potong kue. Sehingga seseorang tersebut akan meminta kompensasi untuk hilangnya daya beli uang akibat inflasi. Selanjutnya alasan ini banyak keganjilan jika kita mau kritis menilai asumsi yang dijadikan landasan perhitungan nilai waktu uang hanya didasarkan pada kondisi terjadinya inflasi. Karena dalam kenyataan kondisi ini tidak lengkap (non exhaused condition). Karena dalam setiap perekonomian selalu ada keadaan inflasi dan deflasi. Sehingga tidak relevan jika hanya keadaaan terjadi inflasi saja yang menjadi alasan adanya nilai waktu uang, seharusnya tingkat deflasi juga harus diperhitungkan.

\section{Preference Present Consumption to Future Consumption}

Umumnya orang, present consumption lebih disukai dari pada future consumption. Misalkan tingkat inflasi nol, sehingga dengan uang Rp. 1000 seseorang dapat 
membeli lima potong kue hari ini maupun tahun depan. Bagi kebanyakan orang, mengkonsumsi lima potong kue saat ini lebih disukai dari pada mengkonsumsi lima potong kue di tahun depan walaupun tingkat inflasinya nol, sehingga untuk menunda konsumsi lima potong kue sampai tahun depan seseorang akan meminta kompensasi.

\section{Kritik terhadap penerapan konsep Time value of money}

Saat ini penerapan konsep time value of money didasarkan pada judgement nilai yang subyektif dan bauran estimasi. Beberapa kesulitan dalam penerapan konsep time value of money adalah sebagai berikut:

a. Teknik nilai waktu uang harus diterapkan, kecuali jika kita menilai cash flow yang pertama (pada project investasi) yang selalu menunjukan tanda negatif, sedangkan semua subsekuen arus kas masuk (di masa yang akan datang) harus menjadi positif. Jika tidak, kemungkinan tidak ada tingkat (bunga) yang unik sehingga akan mendiskon flow back kembali ke investasi semula ( Gambling \& Karim, 1991).

b. Konsep time value of money berasumsi bahwa discounting factor harus positif (Gambling \& Karim, 1991). Asumsi ini juga merupakan sesuatu yang tidak riil. Pada kondisi perekonomian mengalami laju inflasi yang tinggi, discount factor (seperti: tingkat bunga) dapat menjadi negatif. Sehingga anggapan bahwa nilai uang sekarang selalu lebih besar dibanding pada masa yang akan datang tidak selalu benar. Hal ini tergantung pada kondisi pribadi masing- masing, lingkungannya, kemungkinan masa depan dan resiko yang ada pada masa depan.

c. Konsep time value of money mengasumsikan bahwa ada pasar yang efisien untuk cash flow pada masa yang akan datang. Hal ini berarti bahwa pasti ada cash flow akan dihasilkan dimasa yang akan datang dan diinvestasikan secara menguntungkan serta pasti ada pasar seperti ini. Namun dalam kenyataan hal tersebut hanya sebatas harapan dan belum pasti akan terjadi dan dilaksanakan.

d. Konsep time value of money beranggapan bahwa perusahaan mampu melakukan ekspansi yang tidak terbatas pada masa yang akan datang tanpa invalidating model (Gambling \& Karim, 1991). 
e. Tidak ada dasar objektif untuk "pengubahan harapan mengenai aliran kas pada masa yang akan datang kedalam nilai itu sendiri atau ekuivalen tertentu tanpa mengetahui preferensi resiko pengguna informasi, sehingga penyesuaian yang menggunakan discount rate yang subyektif secara konseptual adalah tidak cocok (Hendriksen, 1990).

f. Konsep time value of money hanya menerapkan faktor waktu dan aliran kas yang diharapkan. Maka semua faktor ekonomi, tekhnologi, politik dan sosial lainnya adalah diabaikan. Sebagaimana diketahui profitabilitas aset atau bisnis sangat tergantung pada banyak faktor. Oleh karena itu analisis yang didasarkan pada dua faktor tersebut tidaklah realible.

g. Konsep time value of money tidak cocok untuk akuntabilitas manajemen. Karena metode ini tidak menjadi jelas, apakah pendapatan yang diharapkan melalui metode ini menunjukan pada upaya menajemen atau beberapa faktor lainnya.

h. Saat discounting untuk masa depan, hal ini sering kali lupa bahwa perusahaan itu telah berada pada masa lalu dan sekarang. Kejadian masa lalu dan lingkungan saat ini secara keseluruhan diabaikan, walaupun pada saatnya faktor tersebut tidak relevan.

i. Tujuan time value of money adalah mengestimasi pendapatan perusahaan, yang merupakan hasil dari kejadian pada masa yang lalu. Tetapi tidak menggunakan data masa lalu untuk mengestimasikannya, melainkan menggunakan informasi untuk memprediksi pendapataan di masa depan. Konsep time value of money tidak memberikan suatu kriteria penilaian prediksi yang dibuat oleh manajemen (Hendriksen, 1990: 149).

j. Dalam kehidupan nyata, ketidakpastian adalah mutlak, sedangkan harapan merupakan cerminan dari mood seseorang yang membuat estimasi, yang sangat dipengaruhi oleh optimisme dan pesimismenya. Bagi manusia adalah sulit untuk melihat masa depan secara realistik (Muhammad, 2003).

k. Aliran kas yang diharapkan dimasa depan adalah disesuaikan untuk ketidakpastian dengan menggunakan probabilitas realisasinya. Probabilitas bersifat sangat subjektif. Hal ini akan sama dengan penyesuaian yang dibuat dengan discount rate atas preferensi risiko (Muhammad, 2003).

1. Produktivitas aset sering tergantung pada kombinasinya dengan aset yang lain atau aktivitas itu sendiri. Sehingga dalam praktek, hal ini men- 
jadi amat sulit untuk mengestimasikan aliran kas yang muncul dari salah satu aset tertentu.

Kondisi riil dalam kehidupan bisnis tentu dihadapkan dalam situasi ketidakpastian baik itu berkaitan dengan tingkat pendapatan (return) maupun tingkat resiko yang diakan dihadapi. Sehingga dapat disederhanakan bahwa dalam melakukan aktivitas ekonomi misalnya bisnis tentu masing-masing orang akan berhadapan dengan kemungkinan mendapatkan positive return, no return atau bahkan mendapatkan negative return.

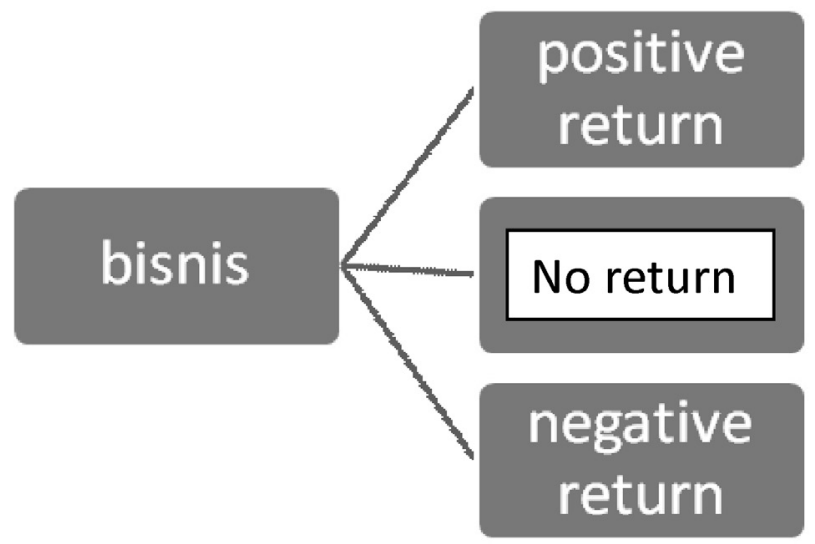

Dalam ekonomi konvensional, ketidakpastian return ( no return dan negative return) akan dikonversikan menjadi kepastian return melalui premium for uncertainty.

\section{Konsep Economic value of time}

Dalam teori ekonomi Islam diakui bahwa manusia memiliki kebutuhan sesuai dengan fitrah dalam dirinya. Namun cara yang ditempuh guna memenuhi kebutuhan tersebut, manusia tidak bebas boleh melakukan hal apa saja sesuai dengan keinginan. Karena manusia dibatasi oleh hukum (syariat) dan nilai-nilai yang diyakininya (akidah dan akhlak). Dalam keuangan Islam tidak terdapat asumsi bahwa sejumlah uang akan memberikan fixed income karena dalam keuangan Islam tidak memiliki konsep fixed pre-determined return melalui konsep bunga (interest based economy). Konsep fixed pre-determined return merupakan 
konsep pemastian keuntungan atas sejumlah uang, sehingga sangat logis jika orang akan lebih suka memegang uang saat ini dibanding nanti, karena ada keuntungan pasti dengan memegang uang saat ini, atau jika seseorang tersebut harus memegang uang tersebut nanti maka harus ada kompensasi atas keuntungan yang "seharusnya' dia dapatkan.

Keuntungan dalam konteks ekonomi Islam haruslah diperoleh setelah menjalankan aktivitas bisnis, yang masih menjadi pertanyaan adalah apa ukuran yang dapat digunakan untuk menetapkan besarnya keuntungan yang diramalkan?, sedangkan dalam keuangan modern kita mengenal adanya interest rate yang dilarang oleh Islam. Dalam ekonomi Islam penggunaan sejenis discount rate dalam menentukan bai' mu'ajjal (membayar tangguh) dapat dibenarkan dengan alasan: (1) jual beli dan sewa menyewa adalah sektor riil yang menimbulkan economic value added (nilai tambah ekonomis) dan (2) tertahannya hak si penjual (uang pembayaran) yang telah melaksanakan kewajiban (menyerahkan barang dan jasa), sehingga tidak dapat melaksanakan kewajibannya kepada pihak lainnya. Demikian juga dengan penggunaan discount rate dalam menentukan nisbah bagi hasil. Nisbah harus dikalikan dengan pendapatan aktual (actual return) bukan dengan pendapatan yang diharapkan (expected return). Pada prinsipnya transaksi bagi hasil berbeda dengan transaksi jual beli atau transaksi sewa menyewa. Dalam transaksi bagi hasil, hubungan yang terjadi adalah hubungan antara pemodal (shahibul maal) dengan pengelola (mudharib). Hak bagi shahibul maal dan mudharib adalah berbagi hasil atas pendapatan atau keuntungan yang diperoleh sesuai dengan kesepakatan awal.

Syariah Islam menganjurkan untuk selalu menginvestasikan uang dalam usaha yang produktif. Investasi dalam usaha yang produktif menjadi inti dari konsep keuangan menurut syariah Islam. Dalam kegiatan investasi kita tidak dapat menuntut secara pasti pendapatan atau keuntungan dimasa depan. Karena hasil dari investasi dimasa yang akan datang sangat dipengaruhi oleh banyak faktor, baik faktor yang dapat diprediksi maupun faktor yang tidak dapat diprediksi. Faktor- faktor yang dapat diprediksikan atau dihitung sebelumnya seperti: (a) banyaknya modal yang dibutuhkan, (b) besarnya nisbah yang disepakati, (c) tingkat perputaran modal. Sedangkan faktor yang tidak dapat dihitung secara pasti adalah return (pendapatan investasi). Sehingga nilai waktu uang yang diformulasikan dalam bentuk bunga tidak sesuai dengan syariah Islam, 
konsep economic value of time menekankan bahwa waktulah yang memiliki nilai ekonomi bukan uang yang memiliki nilai waktu.

\section{Perbandingan konsep Time Value of Money dengan Economic Value of Time}

Hal utama yang membedakan konsep time value of money dengan economic value of time adalah pada konsep time value of money dasar perhitungan pada kontrak adalah berdasarkan bunga, sedangkan dasar perhitungan pada konsep economic value of time adalah nisbah. Konsep economic value of time dalam perhitungannya dapat menggunakan konsep revenue sharing atau profit sharing. Konsep revenue sharing atau profit sharing akan sangat berdampak pada tingkat nisbah yang menjadi perjanjian pada kontrak kerjasama. Konsep cost of fund dalam economic value of time menggunakan Islamic Security Market Line dengan variabel risk free $=0$. Adapun value dari pembiayaan atau investasi yang dilakukan menggunakan metodologi Net Present Value at Risk. Misalkan dalam hal penentuan nisbah bagi hasil, return on capital harus diperhitungkan dalam hal ini return on capital tidak sama dengan return on money. Return on capital sangat tergantung pada jenis bisnisnya dan berkaitan dengan sektor riil. Sedangkan return on money sangat berkaitan dengan interest rate. Penentuan nisbah bagi hasil dilakukan diawal kerjasama dan mmenggunakan project return sebagai dasarnya. Apabila ternyata actual return dari investasi yang dibiayai tidak sama dengan proyeksinya karena ada faktor yang memang tidak dapat diprediksi, maka yang akan digunakan adalah angka actual return bukan angka proyeksi return. Sehingga dalam hal ini menunjukan bahwa Islam tidak setuju dengan konsep time value of money yang memastikan tingkat keuntungan dimasa yang akan datang. Waktu akan memiliki economic value jika dan hanya jika dimanfaatkan untuk kegiatan produktif sehingga menjadi suatu capital dan memperoleh suatu return.

Dalam keuangan Islam uang bukanlah suatu komoditas, hanya sekedar alat menilai barang /jasa atau sebagai alat transasksi. Sehingga ada landasan lain yang digunakan sebagai pijakan dalam pengambilan keputusan keuangan yaitu akhlak, sehingga ketika preferensi seseorang terhadap uang yang dikaitkan dengan waktu menjadi tidak relevan. Ketika seseorang mengambil keputusan investasi secara umum akan membandingkan risk-free interest dengan ekspek- 
tasi keuntungan pada suatu projeck investasi, hal hal ini biasanya konsep time value of money menjadi konsep intinya. Namun jika kita mendasarkannya pada akhlak dan moral Islam, ibaratnya secara ekstrim seseorang akan tetap berinvestasi meskipun sedikit returnnya atau bahkan hanya akan BEP (break even point), jika project investasi tersebut telah memberikan kemanfaatan bagi orang yang menganggur sehingga akan membuka lapangan pekerjaan.

Kuantitas waktu bagi setiap orang adalah sama yaitu 24 jam per hari per tujuh hari per minggu. Namun "nilai waktu" tidaklah selalu sama bagi setiap orang. Sedangkan faktor yang menentukan nilai waktu adalah cara seseorang memanfaatkan waktunya, semakin efektif dan efisien, semakin tinggi nilai waktunya.

\section{Kesimpulan}

Perbedaan konsep time value of money dengan konsep economic value of time adalah terletak pada asumsinya yang memandang bahwa preferensi waktu yang selalu positif. Karena dengan selalu mengasumsikan nilai waktu uang yang selalu positf akan mengarah pada suatu kesimpulan yang ganjil. Misalkan (contoh yang ekstrim) seseorang yang tidak menginvestasikan gajinya (untuk memastikan konsumsi yang lebih tinggi diwaktu yang akan datang) seharusnya dia mengkonsumsi semua gajinya pada hari pertama di awal bulan.

\section{Daftar Pustaka}

Al-Kaff, Abdullah Zaky. 2002. Ekonomi Dalam Perspektif Ekonomi Islam. Bandung: Pustaka Setia. cet ke-1. hal 195.

Ali, Zainuddin. 2008. Hukum Ekonomi Syariah. Jakarta: Sinar Grafika.

Al- Jaziri, Abdurrahman. 1972. Kitab al Fiqh 'ala Mazahib al Arba'ah. Beirut: Dar Al-Fikr.

Fatwa MUI No.1 Tahun 2004

Gambling, T. \& R.A.A Karim. 1991. Business and Accounting Ethics in Islam. London: Mansell. 
Gambling. T. \& R.A.A Karim. 1991. Islam and Social Accounting. Journal of Business Finance and Accounting. Vol. 13. 1.

Hendriksen, Eldon S. 1990. Accounting Theory. Homewood. Illionis: Richard D. Irwin.

Karim, Adiwarman A. 2007. Ekonomi Makro Islami. Rajawali Press. Jakarta.

Muhammad. 2003. Pengantar Akuntansi Syariah. Jakarta: Salemba Empat

Tim Penyusun. 1999. Kamus Perbankan. Jakarta: Kerjasama BI, IBI dan Pusat Pengembangan Bahasa. 